\title{
Are Gaze Shifts a Key to a Translator's Text Segmentation?
}

\author{
Lykke Jakobsen, Arnt
}

Document Version

Accepted author manuscript

Published in:

Poznan Studies in Contemporary Linguistics

DOI:

10.1515/psicl-2016-0015

Publication date:

2016

License

CC BY-NC-ND

Citation for published version (APA):

Lykke Jakobsen, A. (2016). Are Gaze Shifts a Key to a Translator's Text Segmentation? Poznan Studies in Contemporary Linguistics, 52(2), 149-173. https://doi.org/10.1515/psicl-2016-0015

Link to publication in CBS Research Portal

\section{General rights}

Copyright and moral rights for the publications made accessible in the public portal are retained by the authors and/or other copyright owners and it is a condition of accessing publications that users recognise and abide by the legal requirements associated with these rights.

Take down policy

If you believe that this document breaches copyright please contact us (research.lib@cbs.dk) providing details, and we will remove access to the work immediately and investigate your claim. 


\section{Are Gaze Shifts a Key to a Translator's Text Segmentation? Arnt Lykke Jakobsen}

Journal article (Post print version)

Cite: Are Gaze Shifts a Key to a Translator's Text Segmentation? . Lykke Jakobsen, Arnt. In: Poznan Studies in Contemporary Linguistics, Vol. 52, No. 2, 2016, p. 149-173.

D01: 10.1515/psic|-2016-0015

Uploaded to Research@CBS: July २016

(C) 2016. This manuscript version is made available under the CC-BY-NC-ND 4.0 license http://creativecommons.org/licenses/by-nc-nd/4.0/ 


\title{
Are gaze shifts a key to a translator's text segmentation?
}

\author{
Arnt Lykke Jakobsen, Copenhagen Business School
}

\begin{abstract}
Keystroke logging has demonstrated that a translator's text production can be broken down into units separated by pause boundaries (Dragsted 2004, 2005, 2010). Reading research has not identified analogous boundaries, as the only interruptions in a reader's visual attention to a text are often only blinks. However, in an experimental setup with tracking of a translator's gaze movements across a screen showing the source text and (emerging) target text, gaze data show the translator's shifts of visual attention between the two texts. Can such shifts be seen as an index of content processing units? And do such shifts give us more accurate information about segmentation or more information than keystroke intervals? Using a rather poorly calibrated recording of just one translator's translation of a single sentence (within a longer task) for illustration, the paper seeks to tentatively explore the feasibility of identifying segments, understood as processing units, on the basis of gaze shifts, and to inquire into what motivates gaze shifts. It also seeks to illustrate how much our interpretation of gaze representations, not least suboptimal representations, depend on a theory of reading.
\end{abstract}

Key words: translation process research, segmentation, attention shifts, attention units, processing units, translation units, eye tracking.

\section{Introduction: Segmentation based on logged keystroke data}

If one observes how a translation is typically typed, perhaps the most striking feature is that it is an uneven process with short periods of typing alternating with pauses. This is particularly evident in unskilled translators. With more skilled translators, the typing process may be more even and quite rhythmical, but it typically still consists of sequences of typing alternating with pauses with no keyboard activity. Few translators are capable of producing a written translation without some kind of sequencing or segmentation being manifested.

Pauses as indicators of processing have been investigated for many years, e.g., by Goldman-Eisler (1972), Butterworth (1980), Baddeley (1986), Schilperoord (1996), Jakobsen (2003), Immonen and Mäkisalo (2010), and many more. Pauses have been viewed as important indicators of cognitive processes. In most of these studies, pausing has been studied as a feature of speech. Goldman-Eisler studied pauses to investigate the 'psychological reality' (1972: 103) of syntactic structures and contrasted pausing in spontaneous speech with what she found when text was read out loud and found that the distribution of pauses was quite different. Schilperoord studied lawyers' dictation of routine letters and found fine correlation between the duration of pauses and linguistic units at various levels. Immonen and Mäkisalo compared monolingual text production (native Finnish speakers writing a text in Finnish) with bilingual text production into the L1 (native Finnish speakers translating from English into Finnish) and found that at each linguistic level, all the way from inter-keystroke intervals, across syllables 
and up to the level of clauses (but not beyond), pauses were longer in bilingual text production than in monolingual text production indicating that bilingual text production involved additional cognitive effort at every level. At sentence and paragraph levels, pauses between units were longer in monolingual than in bilingual production indicating that the forward planning effort required in monolingual text production at sentence level and above (at the 'macro-planning level', Butterworth 1980: 159) was stronger than the effort required at these levels in bilingual production. In other words, the extra effort required for bilingual production (in comparison with monolingual production) is overshadowed at these higher levels by the forward planning effort, which is required in monolingual production, but not in translation. Thus keystroke logging makes it apparent that hesitation phenomena similar to those observable in speech can be observed in a translator's typing of a target text. Pausing, therefore, is not only a strong indicator of the rhythmical nature of language processing but also provides evidence of the amount of cognitive effort invested at any given point in the process.

Keystroke-based segments have most often been identified by application of a fairly randomly selected temporal 'pause value' segment boundary criterion, mostly between 1 and 5 seconds (for a discussion, see Dragsted 2004: 104-105; Alves and Vale 2009: 255). The assumption has been that there is a correlation between pause duration and processing effort, such that longer pauses indicate greater mental effort. Within segments, it is possible to identify sub-segments, again from the duration of keystroke intervals, but segmentation can also be studied from other evidence such as eye movements, as will be shown below.

A keystroke-based representation of one translator's typing of "Gestern wurde er nach langem Gerichtsverfahren des vierfachen Mordes schuldig gesprochen" as a translation into German of the sentence "Yesterday, he was found guilty of four counts of murder following a long trial." (from a short newspaper text) could look like this:

$[\cdot 01.529]$ Gestern $\bullet$ wurde $\cdot[\cdot 00.874]$ er $\bullet[\cdot 00.944]$ des $\bullet$ vierfachen $\bullet$ Morde $[\cdot 01.560]<\triangleleft<[\cdot 00.905]$ in $\bullet$ Folge $\bullet$ eine $\mathrm{s} \cdot[\cdot 00.608] \mathrm{la}[\cdot 04.493]<<$ nach $\cdot[\cdot 00.359]$ lange $[\cdot 00.843] \mathrm{m} \cdot \mathrm{F}[\cdot 00.359][$ Shift+Back]Ver[$[\cdot 00.375]<<[$ Shift+B ack]Gerichtsverfahren $\bullet[\cdot 00.983]$ des $\bullet$ vierfachen $\bullet$ Mordes $\bullet[\cdot 00.765]$ schg $[\cdot 00.702]<u[\cdot 00.234]$ ldig $\bullet$ gesproch en. $\cdot[\cdot 04.134]$

Figure 1. Keystroke representation with suppression of pauses shorter than $250 \mathrm{~ms}$ (with one slightly shorter exception at the end).

In this representation, only keystroke intervals at $250 \mathrm{~ms}$ and above have been represented (with one exception). An effect of this is that we see how pauses $250 \mathrm{~ms}$ and above tend to occur between full words or phrases, and only within words if a typo was accidentally made or typing of a planned translation was interrupted because the translator had suddenly thought of a different solution. The translation of 'Yesterday, he was found guilty of four counts of murder' at first proceeded unproblematically, including the transposition involved in translating 'he was' to 'wurde er'. The missing ' $s$ ' at the end of 'Morde' followed by a lengthy pause and several backspaces indicates that a new translation had occurred to the translator. The new translation (again) involved rearrangement of the information structure and fronting of the final adverbial phrase 'following a long trial'. The translator appeared not to have taken this final adverbial phrase into consideration when the previous phrase was typed. Then, just as the translator was going to type 'langen', typing was broken off (after only 'la' had 
been typed) by a new idea for translating 'following'. This new idea concerned the interpretation and translation of 'following'. The causal or resultative interpretation suggested by 'in Folge' was discarded and replaced with a purely temporal interpretation ('nach' [after]). Making this change and thinking out the necessary rearrangement of the construction took about four and a half seconds, by far the longest typing interval in the translation of this sentence. Finally, the generic 'Verfahren' [proceeding(s)] was specified into 'Gerichtsverfahren' [legal proceeding(s)], and the rest of the sentence was typed with only an accidental typo 'schg' causing a slight delay in production.

How we choose to divide a keystroke representation into segments will depend on the level of granularity of our analysis. In the literature, segment boundary criteria have generally been set at durations between $1 \mathrm{~s}$. and $5 \mathrm{~s}$. In the case under examination our translator was a very fast typist frequently reaching speeds of about ten keystrokes per second. By a $1 \mathrm{~s}$. boundary criterion, our example breaks down into only three segments, the last of which is intuitively too long to be interpreted as having been processed as a single segment or 'chunk' of information:

1. $[\cdot 01.529]$ Gestern $\bullet$ wurde $\cdot[\cdot 00.874]$ er $\cdot[\cdot 00.944]$ des $\bullet$ vierfachen $\bullet$ Morde

2. $[\cdot 01.560]<<<[\cdot 00.905]$ in $\bullet$ Folge $\bullet$ eines $\cdot[\cdot 00.608] \mathrm{la}$

3. $[\cdot 04.493] \varangle<$ nach $\cdot[\cdot 00.359]$ lange $[\cdot 00.843] \mathrm{m} \bullet F[\cdot 00.359][$ Shift+Back]Ver $[\cdot 00.375] \varangle<[$ Shift+Back] Gerichtsverfahren $\bullet[\cdot 00.983]$ des $\bullet$ vierfachen $\bullet$ Mordes $\bullet[\cdot 00.765]$ schg[$[\cdot 00.702]<u[\cdot 00.234]$ ldig $\bullet$ gespr ochen.

Figure 2. Segmentation by a $1 \mathrm{~s}$. boundary criterion.

By just shortening the boundary criterion to 0.9 s., we get a doubling of segments and an intuitively, cognitively and grammatically more attractive view of the chunks the translator may have worked with:

1. $[\cdot 01.529]$ Gestern $\bullet$ wurde $\cdot[\cdot 00.874]$ er $\bullet$

2. $[\cdot 00.944]$ des $\bullet$ vierfachen $\cdot M o r d e$

3. $[\cdot 01.560]<4<$

4. $[\cdot 00.905]$ in $\bullet$ Folge $\cdot$ eines $\cdot[\cdot 00.608]$ la

5. $[\cdot 04.493] \varangle$ nach $\cdot[\cdot 00.359]$ lange $[\cdot 00.843] \mathrm{m} \bullet F[\cdot 00.359][$ Shift+Back]Ver[$[\cdot 00.375] \triangleleft 4[$ Shift+Back] Gerichtsverfahren•

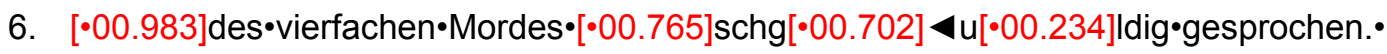

Figure 3. Segmented keystroke representation based on 900 ms boundary criterion.

The 900 ms criterion increases the number of segments to six, one of which (the $3^{\text {rd }}$ ) was the deletion of a chunk which was in the wrong place but would be used later, and one (the $4^{\text {th }}$ ) was subsequently discarded (at the beginning of the $5^{\text {th }}$ segment) and replaced by the solution with 'nach'.

Further subdivision is possible, but obviously the shorter the duration of the boundary, the more fragmentary the content. In our one-sentence example, a segment boundary criterion of any duration between 400 and $600 \mathrm{~ms}$ would yield the following ten segments, which are still not very fragmented (Carl and Kay 2011: 954): Gestern wurde / er / des vierfachen Morde / ४४ ४ / in Folge eines / la / $\varangle$ ४nach langem Gerichtsverfahren / des vierfachen Mordes / schg / ४ Idig gesprochen.

The optimally relevant criterion depends on the researcher's focus of interest and on our ability to establish a plausible connection between a written segment and a processing unit. The mind of a translator can attend to a whole range of phenomena, from high-level conceptualisation of the meaning 
of whole sentences and texts to micro-level phenomena like a spelling mistake. Attention is like an allpurpose zoom lens which can flexibly zoom in on tiny details at one moment and turn to a wide angle view the next instant and can keep multiple perspectives from different levels active at the same time, creating contexts within contexts. As keystroke data can be represented with flexible granularity depending on the level of temporal resolution selected, such data can provide evidence of both high and low-level processing, but perhaps has its particular strength at the low-level end.

It is noteworthy that the duration of pauses appears to be clearly stratified. In this translator's production process inter-keystroke intervals were mostly around $100 \mathrm{~ms}$. One pause lasting $234 \mathrm{~ms}$ has been exceptionally included because it appears to be part of a complex reaction to an accidental typo and, although shorter than $250 \mathrm{~ms}$, is evidence of some slight dysfluency. The pause was more than twice as long as the average inter-keystroke interval when typing was fluent. In the typing of the rest of the expression (Idig•gesprochen) the average keystroke interval was less than $100 \mathrm{~ms}$ (15 keystrokes in $1404 \mathrm{~ms}$ ). In the interval between $250 \mathrm{~ms}$ and $900 \mathrm{~ms}$ there were only eight pauses, four of which were associated with editorial changes, four most probably with more complex decision-making and monitoring. Of the longer pauses, one boundary pause (between segments 4 and 5 ) was exceptionally long, but the others were all, roughly, in the interval between $0.9 \mathrm{~s}$. and $1.5 \mathrm{~s}$. Thus we find four categories of pauses: One exceptionally long pause (1), five segment boundary-length pauses (5), a middle category (range: 234-874 ms) associated with editorial and 'second thought' changes (9), and short inter-keystroke and slightly longer inter-morpheme and inter-word pauses (147), mostly in the 80 to 200 ms range.

\section{Segmentation based on gaze data}

As all the evidence used to support the ideas suggested in the present article comes from a single recording of one individual translator's typing of a translation into German of just one sentence from a short newspaper article, no claim can be made with respect to the generalisability of the observations made here. The recording shows the gaze activity of a highly expert and fast-working translator. The duration of the activity analyzed was just over 18 seconds and came three sentences into a trial text (starting two minutes and 40 seconds into the task) at a point when, after a slow start, the translator appeared to have become familiar with the task and had worked up considerable overall translation and typing speed.

Technically, as will appear from the screenshots below, the recording is not among the best. Inaccurate calibration has led to gaze samples and fixations being both horizontally and vertically displaced. Horizontally, the data has been projected to a virtual screen that was narrower than the actual screen. ${ }^{1}$

\footnotetext{
${ }^{1}$ In addition to observation of the overall projection of gaze data on the screen, there are several other clues that can help researchers make the necessary adjustments to correctly map fixations to words in a less-then-perfect recording. Dynamic replay of a file provides many such clues. For example, the static representation in Fig. 10 (below) displays fixations (in Win2) on the word 'Gerichtsverfahren', but the dynamic replay clearly shows that here the gaze was on the translator's typing of 'des vierfachen'.
} 
This means that in order to map fixation circles to the words which were fixated and presumably read, the proper location of fixation circles has to be stretched left and right from the centre toward the margins. Vertically, the opposite phenomenon can be observed. On this axis, fixations are above the line they belong to in the top half of the screen (less and less toward the horizontal middle of the screen) and below the line in the bottom half, more and more the further below the horizontal middle they occur). Nevertheless, the recording is accurate enough to make it possible to know with a high degree of probability what words were looked at. Our theory of how reading is done can help us decide, in many cases, what word a fixation should be mapped onto. Knowledge of technical aspects of eyetracking is also highly relevant. Fortunately, for our present purposes, information in the raw data makes it very clear when there was a shift of the gaze between the two windows, the upper ST window (Win1) and the lower target text window (Win2).

Keystroke-based segments come in all sizes. In a keylog, the smallest segment is a single keystroke, a slightly larger segment may be a (graphic) morpheme or syllable, a still larger segment might be a (graphic) word, etc., depending on the duration and distribution of keystroke intervals. With gaze data, the situation is somewhat different. An eyetracker records the position of the eyes relative to the screen many times per second, typically between 60 and 2000 times ('samples') per second. This is how the machine works, however, not how a human translator segments information. The human eye moves from one fixation to another, connecting two fixations with a quick jump ('saccade'). Fixations can be viewed technically as bundles of samples, typically across $200 \mathrm{~ms}$ to $300 \mathrm{~ms}$. A trained reader does not fixate one character at a time, but normally has one fixation per content word. From a behavioural as well as a cognitive point of view, therefore, it could be argued that the smallest reading segment (for a trained reader) is a content word bounded by a saccade.

What is more interesting than minimal segments in themselves, however, is how they combine into larger processing units, represented in one or several words. It is true, as Chesterman wrote (1989: 5) that: "Translating is something that people do with words". Translation begins and ends in verbal representation (words), but how a translator gets from the source language (SL) words to the target language (TL) words is still much debated. The process of connecting or 'mapping' verbal representations in two different languages not only requires consideration of words and grammatical constraints working on them, but very much also of how their meaning, the mental representation(s) evoked by words, can most adequately be aligned. 'What are the words in the TL that will most aptly express the mental representation activated by the source text?' is the question a translator is constantly confronted with. According to de Groot (1997: 29ff.), translation is either horizontal or vertical. Either words (word forms) are bilingually paired in a translator's memory so that no comparison of two meanings is involved (horizontal translation), or else the translator has to compute meaning by comparing and evaluating a SL word or expression with one or several TL words or expressions for their capacity to activate relevantly similar meaning. Can gaze data illuminate this distinction? 
From observation of the gaze behaviour of this particular translator, it was evident that she ${ }^{2}$ mostly read about seven words ahead (including the 'anchor' words) when reading 'new' source text (ST). This ST reading strategy can be characterised as sparse forward reading, meaning that she typically read only as much new ST text as was necessary to have a translatable portion. This is a strategy which involves considerable risk because information may appear further on in the ST sentence ('downstream') which forces the translator to delete, change or rearrange already translated and typed text. For a fast typist, it may make cognitive sense to take such calculated risks. Once a translatable unit has been read and translated, cognitive capacity is freed and available for the next translatable unit. The possibly unconscious, routinised calculation appears to be that the advantage gained from freeing cognitive capacity is greater than the risk, i.e., greater than the penalty involved in having to revise existing text.

A further possible advantage that can be achieved by this method of coordinating reading and typing is that when there are no particular obstacles to translation, sparse forward reading makes it possible for the translator-typist to maintain fairly fluent, fast text production. In the passage selected for analysis here, as we shall see, the strategy did encounter obstacles, but they were quickly overcome without deviation from the sparse forward reading strategy.

The next section presents a detailed narrative of the translator's gaze path through the ST and the target text (TT) during the 18.5 seconds it took the translator to translate the sentence we are concerned with in the present analysis. The gaze path will be illustrated with eight screenshots (Figures 4-11), which unfortunately do not show the dynamics of the gaze movements. ${ }^{3}$ The captions and running comments will hopefully help give an impression of the main directions and sequences of gaze movements.

\section{Analytical narrative of gaze data during the translation of sentence four}

After moving the gaze up into Win1 (Shift 1) to fixate the first word ('Yesterday') of the sentence under analysis (sentence four of the text), the translator was ready to type the German translation ('Gestern') and started doing so while continuing to read more new text ('he was found guilty of four'), see Fig 4). That is to say, 'Yesterday' was apparently perceived as an independent translatable unit, for the typing of the translation of it was initiated immediately while reading of new text for the full (or next) translatable unit was in progress. A 'translatable unit' is a purely subjective notion. It is what a translator perceives as being a sufficient piece of text to initiate translation of. There is support for interpreting the translator's treatment of 'Yesterday' as an independently translatable unit in the fact that the typing of 'Gestern' started immediately after the word had been read. It would then be a classic instance of horizontal translation. On the other hand, reading was continued in Win1 without any gaze shift to the target text (TT) input window (Win2), which suggests that although it could be translated straightaway,

\footnotetext{
${ }^{2}$ No information about participant P01 (U88) is included in the TPR-DB metadata, and the person's identity is unknown to the author. The attribution of feminine gender is arbitrary.

${ }^{3}$ Readers who would like to view the dynamics can download the open access TPR-DB and the Translog II software at https://sites.google.com/site/centretranslationinnovation/. The file name of the recording here analysed is P01_T1.xml in the SG12 experiment.
} 
it was (also) regarded as part of a larger translatable unit. Reading in Win1 proceeded to the end of the line so that altogether seven new words were read in this first reading for new text. With 'he was found guilty of four [??]' the translator had the basic structural elements of the main clause: subject ('he'), passive form of verb ('was found') and verb complement ('guilty of four [??]'), with the structural challenge, however, that in German the main verb form must be kept in mind until the end of the sentence.

Obviously, some ST reading is always necessary in order for the translator to have something to translate. This fundamental motivation for a gaze shift to the ST is illustrated in this first reading activity, in which the translator was reading new ST until shehad processed and constructed enough meaning to make up what the translator took to be a translatable unit. As will appear, there were two further ST reading processes aiming similarly at harvesting new text. That is to say, the sentence under analysis was read in three relatively short forward moves, the second adding three new words, and the third adding four.

The first sequence also illustrates that our translator was capable of managing to type in Win2 without looking away from the ST window (Win1). Such overlapping reading and writing has been taken as indicative of parallel processing (Balling et al. 2014: 232) and may well be. What can be safely said is that the combination of gaze and keystroke data makes it very clear that our translator was frequently reading and typing at the same time, in fact systematically aiming at ensuring, by reading ahead, that the fingers at the keyboard would not have to wait for something to type.

Having read 'Yesterday, he was found guilty of four' and having concurrently typed 'Gester', but not yet the final ' $n$ ', the translator's visual attention was shifted down to Win2 (Shift 2). A shift of attention to the TT input window may have several purposes. Here, the most obvious purpose was for the translator to ensure that TT was being produced as planned and expected, as much typing was being done 'blindly', i.e., without concurrent visual attention (without 'visual monitoring'). ${ }^{4}$

\footnotetext{
${ }^{4}$ Visual monitoring is only one kind of monitoring that may be active. A touch typist is often very responsive to tactile feedback from the fingertips.
} 
Plot $0161.298 / 0630.899=26 \%$ | $\mid$ W Speed: $1 \%$ Go: $0000.000 \mathrm{~ms}$ Collect Import pausing

Killer nurse receives four life sentences

Hospital nurse Colin Norris was imprisoned for life today for the killing of four of his patients. 32 year ol folliks from Glasgow killed the four women in 2002 by giving them large amounts of sleeping medicinesterday, he was found guilty of four counts of murder following a long trial. He was given four life sentences, oneforeach of the killings. He will have to serve at least 30 years. Police officer Chris Gregg said that Norris had been acting strangely around the hospital. Only the awareness of other hospital staff put a stop to him and to the killings. The police have learned that the motive for the killings was that Norris disliked working with old people. All of his victims were old weak women with heart problems. All of them could be considered a burden to hospital staff.

Krankenpfleger des Todes wird vierfach zu Lebenslänglich verurteilt Der im Krankenhaus angestellte Krankenpfleger Colin Norris wurde für den Mord an vier seiner Patienten heute zu einer lebenslänglichen Gefängnisstrafe verurteilt. Der 32-jährige Norris aus Glasgow tötete die vier Frauen 2002, indem er ihnen große Mengen an Schlafmedikamenten verabreichte. Gester

Figure 4. Time frame represented: 160112 to $161298 \mathrm{~ms}$. Circles represent fixations. Green dots represent right-eye samples, red dots left-eye samples. Note earlier comments on the displacement of represented fixations. The translator's gaze first moved up from the cursor position in Win2 (Shift 1) to fixate the word 'Yesterday' in the ST (Win1). Then followed fixations on 'he was found guilty of four' while 'Gester' was being typed in Win2 with no visual attention. At the end of this $1.2 \mathrm{~s}$. sequence, the gaze travelled down to Win2, as seen in the sample dots from the rightmost fixation in Win1 to the cursor position in Win2 (after 'Gester').

In Win2 (Fig. 5), the translator first visually attended to the typing of '(Gester)n wurde'. Again the shift of visual attention to Win2 served the purpose of ensuring that typing was being done correctly (visual monitoring of the typing activity). This inspection lasted $0.7 \mathrm{~s}$. At this point, where typing was also hesitant (around 'er'), the translator was evidently short of something executable to translate and therefore needed to read new ST text, so the gaze was shifted up to Win1 again (Shift 3) to read what 'he' was found guilty of. After rereading 'found guilty of four', thereby anchoring the reading of unseen new text in old, previously read text, she shifted the gaze left to the beginning of the next line to read 'counts of murder' for the first time. This time six words in all were read, of which only the last three had not been seen before. At this point the translator stopped reading, having now captured an additional new translatable unit, and the gaze started to move downward to the cursor input position in Win2 (Shift 4) where 'er' had meanwhile been hesitantly typed in continuation of the translation of what was translatable and executable in the previous unit.

Once again, the aim of the gaze shift to the ST in Win1 was to harvest new text. The need to read new ST arose already after the translation of 'Yesterday, he was' ('Gestern wurde er') had been thought out and typed because translation of a main part of the previously found translatable unit ('found guilty') could not be immediately executed because of constraints from German syntax, and whatever 'he' was guilty of would have to come first. As was typical of this translator (and many others), the reading for new text 
was done by first reading text which had been read earlier, i.e., 'anchoring' new text in old text, and then reading on until the next translatable unit was found.

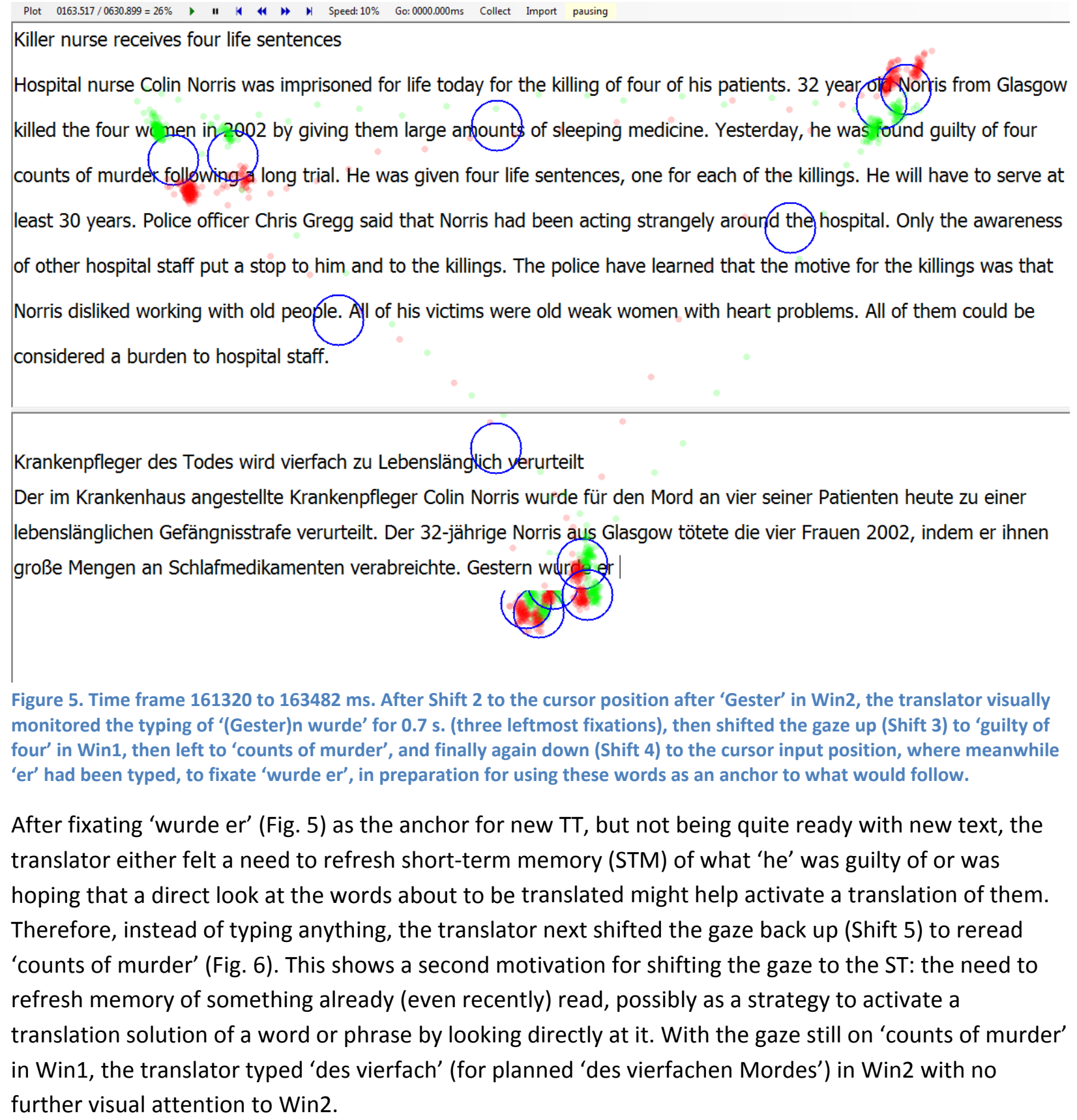

Figure 5. Time frame 161320 to 163482 ms. After Shift 2 to the cursor position after 'Gester' in Win2, the translator visually monitored the typing of '(Gester)n wurde' for $0.7 \mathrm{~s}$. (three leftmost fixations), then shifted the gaze up (Shift 3) to 'guilty of four' in Win1, then left to 'counts of murder', and finally again down (Shift 4) to the cursor input position, where meanwhile 'er' had been typed, to fixate 'wurde er', in preparation for using these words as an anchor to what would follow.

After fixating 'wurde er' (Fig. 5) as the anchor for new TT, but not being quite ready with new text, the translator either felt a need to refresh short-term memory (STM) of what 'he' was guilty of or was hoping that a direct look at the words about to be translated might help activate a translation of them. Therefore, instead of typing anything, the translator next shifted the gaze back up (Shift 5) to reread 'counts of murder' (Fig. 6). This shows a second motivation for shifting the gaze to the ST: the need to refresh memory of something already (even recently) read, possibly as a strategy to activate a translation solution of a word or phrase by looking directly at it. With the gaze still on 'counts of murder' in Win1, the translator typed 'des vierfach' (for planned 'des vierfachen Mordes') in Win2 with no further visual attention to Win2. 
Plot $0165.339 / 0630.899=26 \%$ " $\mid$ " Speed: $1 \%$ Go: $0000.000 \mathrm{~ms}$ Collect Import pausing

Killer nurse receives four life sentences

Hospital nurse Colin Norris was imprisoned for life today for the killing of four of his patients. 32 year old Norris from Glasgow killed the four yopery 2002 by giving them large amounts of sleeping medicine. Yesterday, he was found guilty of four counts of murder fortlonying a long trial. He was given four life sentences, one for each of the killings. He will have to serve at least 30 years. Police officer Chris Gregg said that Norris had been acting strangely around the hospital. Only the awareness of other hospital staff put a stop to him and to the killings. The police have learned that the motive for the killings was that Norris disliked working with old people. All of his victims were old weak women with heart problems. All of them could be considered a burden to hospital staff.

Krankenpfleger des Todes wird vierfach zu Lebenslänglich verurteilt

Der im Krankenhaus angestellte Krankenpfleger Colin Norris wurde für den Mord an vier seiner Patienten heute zu einer lebenslänglichen Gefängnisstrafe verurteilt. Der 32-jährige Norris aus Glasgow tötete die vier Frauen 2002, indem er ihnen große Mengen an Schlafmedikamenten verabreichte. Gestern wurde er des vierfach|

Figure 6. Screenshot of gaze replay from 163498 to 165399 ms showing that the typing of 'des vierfach(en Mordes)' was done in Win2 (with no visual attention) while 'counts of murder' was visually attended to in Win1.

Fig. 7 includes the data in Fig. 6 and adds the two new fixations during which the translator read 'following a long trial' for the first time. Routinely (for this translator), she started to read ahead for the next translatable unit, while the typing of the translation of the previous unit was concurrently in progress. The duration of the first fixation was 316 ms; of the second fixation it was 493 ms. Both values were longer than the average duration of fixations, which indicates that reading was particularly intense here and possibly accompanied by surprise and intense mental effort. Both fixations occurred while 'vierfachen' was being typed in Win2. The concurrent typing activity might be assumed to have had a lengthening effect on fixations, but in other instances in the translation it did not, so attention was clearly heightened here. As can be seen from the screenshot, the reading activity did not at first interrupt the typing that was in progress, which continued at a high speed of close to ten keystrokes per second. However, typing was finally brought to a stop, before the final ' $s$ ' was added to 'Morde'. The immediate outcome of the intense processing going on during the two new Win1 fixations was a decision to shift the gaze to Win2 (Shift 6) and have another look at the part of the translation the translator had now decided was in need of revision. This illustrates yet another function of gaze shifts from Win1 to Win2, viz. to read TT with a view to editing it. 


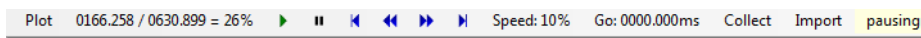

Killer nurse receives four life sentences

Hospital nurse Colin Norris was imprisoned for life today for the killing of four of his patients. 32 year old Norris from Glasgow killed the four yomen $1.20,2$ y givir them large amounts of sleeping medicine. Yesterday, he was found guilty of four counts of murder following a long trial. He was given four life sentences, one for each of the killings. He will have to serve at least 30 years. Police officer Chris Gregg said that Norris had been acting strangely around the hospital. Only the awareness of other hospital staff put a stop to him and to the killings. The police have learned that the motive for the killings was that Norris disliked working with old people. All of his victims were old weak women with heart problems. All of them could be considered a burden to hospital staff.

Krankenpfleger des Todes wird vierfach zu Lebenslänglich verurteilt Der im Krankenhaus angestellte Krankenpfleger Colin Norris wurde für den Mord an vier seiner Patienten heute zu einer lebenslänglichen Gefängnisstrafe verurteilt. Der 32-jährige Norris aus Glasgow tötete die vier Frauen 2002, indem er ihnen große Mengen an Schlafmedikamenten verabreichte. Gestern wurde er des vierfachen Morde|

Figure 7. Screenshot of gaze replay from 163498 to 166258 ms showing two additional fixations (in Win1) to those in Fig. 6 on 'following a long trial' while typing of '(vierfach)en Morde' was done concurrently without visual attention. After reading the new passage, the translator decided to shift the gaze (Shift 6) to the cursor input position in Win2 to inspect the most recently typed target text.

After 'wurde er des vierfachen Morde' had been read and reread for just over 1.5 seconds and before a final 's' was added to 'Morde', a decision was made to delete 'des vierfachen Morde' so that a translation of 'following a long trial' (held in STM) could be inserted and come first. 
Plot $0175.702 / 0630.899=28 \%$ |

Killer nurse receives four life sentences

Hospital nurse Colin Norris was imprisoned for life today for the killing of four of his patients. 32 year old Norris from Glasgow killed the four women in 2002 by gilng them large amounts of sleeping medicine. Yesterday, he was found guilty of four counts of murder following a To, hg trial. He was given four life sentences, one for each of the killings. He will have to serve at least 30 years. Police officer Chris Gregg said that Norris had been acting strangely around the hospital. Only the awareness of other hospital staff put a stop to him and to the billings. The police have learned that the motive for the killings was that Norris disliked working with old people. All of his victims were old weak women with heart problems. All of them could be considered a burden to hospital staff.

Krankenpfleger des Todes wird vierfach zu Lebenslänglich vextrteilt

Der im Krankenhaus angestellte Krankenpfleger Colin Norris wurde für den Mord an vier seiner Patienten heute zu einer lebenslänglichen Gefängnisstrafe ve)urteilt. Der 32-jährige Norris aus Glasgow tötete die vier Frauen 2002, indem er ihnen große Mengen an Schlafmedikamenten verabreichte. Gestern wurde er in Folaresietes la

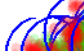

Figure 8. Screenshot of 166258 to 175702 ms showing new solution following repeated reading of 'wurde er des vierfachen Morde' (1.5 s.) ending in the words being deleted. Instead 'in Folge' was typed, followed by a gaze shift (Shift 7) to Win1 to reread 'following a long trial', with concurrent typing of 'eines la'.

The first translation the translator thought of appears to have been 'in Folge eines langen Gerichtsverfahren', and after two more seconds 'in Folge' had been typed with visual monitoring. The choice of 'in Folge' may have been triggered by the graphic similarity of 'following' and 'Folge' and may illustrate the mimetic impulse that translators do not always succeed in effectively inhibiting (cf. also the 'literal default' idea propounded by Ivir (1981), Tirkkonen-Condit (2005) and others).

After deleting 'des vierfachen Morde' and typing 'in Folge', the translator shifted the gaze briefly to Win 1 (Shift 7) to refresh the memory of what came after 'following' (Fig. 8). Typically, the gaze was first anchored in the remembered and already translated word ('following') before moving on to the text ('a long trial') that needed to be refreshed in the translator's STM. This information update took 1.1 seconds and was immediately followed by the typing of 'eines la' and by a shift (Shift 8) of the gaze to Win2, but not, as one would expect, to continue the typing activity with '(eines la)ngen Gerichtsverfahren'. Typing was discontinued and very intensive reading and rereading of the solution just typed was initiated. The translator was obviously not happy with the translation, but did not immediately have a better solution. After intensive reading for more than four seconds, the translator finally decided to delete 'in Folge' and replace it with another solution (seen in Fig. 9).

The function of Shift 7, like that of Shift 5, appears to have been to keep the currently processed ST fragment clearly in focus during translation. Many translators seem to like to have a fresh, very recent view of the ST unit under translation, making the recent eye-key span measure very short. Timarová et al. (2011: 132; cf. also Dragsted and Hansen 2008: 18) also found short values for the eye-key span from 
the last fixation in a group of professional translators. The exact wording of a translatable ST unit appears to quickly lose its desired freshness in STM, so we often find this gaze behaviour, where the translator visually revisits the relevant portion of ST immediately before typing the translation of it.

Shift 8 was not made to monitor recently typed text or text being typed, for recently typed text had already been monitored, and no new text was being typed. It shows how the translator's attention was shifted to reading and evaluating the solution just typed, but still not fully accepted.

As soon as a new solution had been found, with 'nach' replacing 'in Folge', the translator quickly typed the new solution 'nach langem Gerichtsverfahren' without shifting the gaze to refresh STM content. Instead, the translator visually monitored the typing of the new solution as if to make sure it was properly rescued and would bring an end to a very effortful processing interlude.

Hlot $0181.829 / 0630.899=29 \%$, " 4 " M Speed: $1 \%$ Go: 0160.00000 collect Import pausing

Killer nurse receives four life sentences

Hospital nurse Colin Norris was imprisoned for life today for the killing of four of his patients. killed the four women in 2002 by giving them large amounts of sleeping medicine. Yesterday, he was found guilty of four counts of murder following a long trial. He was given four life sentences, one for each of the killings. He will have to serve at least 30 years. Police officer Chris Gregg said that Norris had been acting strangely around the hospital. Only the awareness of other hospital staff put a stop to him and to the killings. The police have learned that the motive for the killings was that Norris disliked working with old people. All of his victims were old weak women with heart problems. All of them could be considered a burden to hospital staff.

Krankenpfleger des Todes wird vierfach zu Lebenslänglich verurteilt

Der im Krankenhaus angestellte Krankenpfleger Colin Norris wurde für den Mord an vier seiner Patienten heute zu einer lebenslänglichen Gefängnisstrafe verurteilt. Der 32-jährige Norris aus Glasgow tötete die vier Frauen 2002, indem er ihnen große Mengen an Schlafmedikamenten verabreichte. Gestern wurde er nach langem Gerichtsverfahren

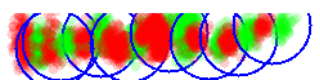

Figure 9. Screenshot of 175702-181829 ms showing the 'nach' solution for 'following' with gaze shift up (Shift 9) at end to Win1 ('he was found guilty').

After the decision to opt for 'nach', the structure of the sentence was in place, and it was only a matter of typing out the translation of the rest of the sentence, with just three brief visual revisits to the relevant portions of the ST, which had all already been read several times and only needed to be quickly refreshed.

There were two minor keystroke hiccups in the typing of the early part of 'Gerichtsverfahren', which were immediately noticed and corrected, and when only the last five letters ('ahren') remained to be typed, the gaze was shifted (Shift 9) to Win1 (Figure 9) to reread 'he was found guilty'. 
Having read this far only, the translator's gaze shifted to Win2 (Shift 10) to monitor the typing of the translation of 'of four' ('des vier'). Although the translator had earlier translated the unit ('des vierfachen Morde[s]') and had just had a parafoveal view of 'four', the gaze was shifted back again to Win1 after $1.4 \mathrm{~s}$. (Shift 11), with the six last letters of 'vierfachen' still remaining to be typed, to reread (for the third time) 'guilty of four counts of murder'.

Plot $0183.831 / 0630.899=29 \%$ | | | | W W Speed: $1 \%$ Go: $0000.000 \mathrm{~ms}$ Collect Import pausing

Killer nurse receives four life sentences

Hospital nurse Colin Norris was imprisoned for life today for the killing of four of his patients. 32 year $\$ 1$ Norns from Glasgow killed the four women in 2002 by giving them large aknounts of sleeping medicine. Yesterday, he was found guilty of four counts of murderfollowing a long trial. He was given four life sentences, one for each of the killings. He will have to serve at least 30 years. Police officer Chris Gregg said that Norris had been acting strangely around the hospital. Only the awareness of other hospital staff put a stop to him and to the killings. The police have learned that the motive for the killings was that Norris disliked working with old people. All of his victims were old weak women with heart problems. All of them could be considered a burden to hospital staff.

Krankenpfleger des Todes wird vierfach zu Lebenslänglich verurteilt

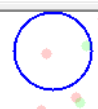

Der im Krankenhaus angestellte Krankenpfleger Colin Norris wurde für den Mord an vier seiner Patienten heute zu einer lebenslänglichen Gefängnisstrafe verurteilt. Der 32-jährige Norris aus Glasgow tötete die viêf Frâuen 2002, indem er ihnen große Mengen an Schlafmedikamenten verabreichte. Gestern wurde er nach langem Gerichtsverfahren des vierfachen |

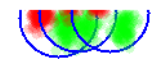

Figure 10. Screenshot of 181829 to 183831 ms showing initial shift of gaze to Win2 (Shift 10), monitoring of the typing of 'des vier', and gaze shift back to Win1 (Shift 11) to reread 'he was found guilty of four counts of (murder)'.

With the gaze still in Win1 while 'Mordes' was being typed in Win2, now for the first time with the final ' $s$ ' (Figure 11), reading continued across 'following a long trial' and then right to 'Yesterday, he was found guilty' (for the fourth time) in preparation for the typing of the final two words of the translation. An accidental typo 'schg' in the execution of 'schuldig' was instantly noticed through tactile feedback, which brought the gaze to Win2 (Shift 12) to monitor the correction and additional typing of 'schuldig gespro(chen).' The inter-keystroke delays before ' $u$ ' and before ' $\mathrm{l}$ ' indicate the careful effort the translator invested to get the correction right. Earlier, during the typing of 'Gerichstverfahren', visual attention was given to the accidental typing of ' $F$ ', but the gaze adjustment this involved was so slight that it merged with the visual screen monitoring of typing output that was going on anyway at the time. The same was the case when the syllable 'Ver' (of 'Verfahren') was typed and then instantly changed to 'Gerichtsverfahren'. But in the case of the ' $\mathrm{g}$ ' being unintentionally typed (in 'schg'), it is clear that an accidental typo noticed from fingertouch feedback can trigger a gaze shift to the scene of the accident in Win2. 
Finally, as was characteristic of this translator's shift pattern, the gaze was shifted to Win1 (Shift 13) with four keystrokes still remaining in 'gesprochen', and the translator was already seeking to identify the next translatable unit(s) in the following ST sentence ('He was given four life sentences').

Plot $0188.480 / 0630.899=30 \%$ " $\|$ Speed: $1 \%$ Go: $0000.000 \mathrm{~ms}$ Collect Import pausing

Killer nurse receives four life sentences

Hospital nurse Colin Norris was imprisoned for life today for the killing off four of his patients. (32 y a d old Norris from Glasgow killed the four women 2003 y givg them targe amounts of sleeping medicine. Yesterday, he was found guilty of four

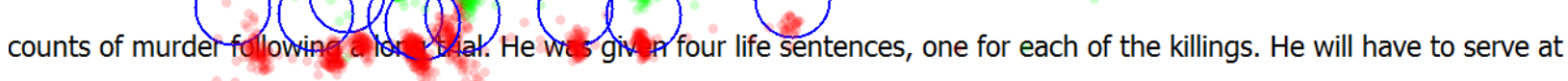
least 30 years. Police officer Chris Gregg said that Norris had been acting strangely around the hospital. Only the awareness of other hospital staff put a stop to him and to the killings. The police have learned that the motive for the killings was that Norris disliked working with old people. All of his victims were old weak women with heart problems. All of them could be considered a burden to hospital staff.

\section{Krankenpfleger des Todes wird vierfach zu Lebenstäpglich verurteilt}

Der im Krankenhaus angestellte Krankenpfleger Colin Norris wurde für den Mord an vier seiner Patienten heute zu einer lebenslänglichen Gefängnisstrafe verurteilt. Der 32-jährige Norris aus Glasgow tötete die vier Frauen 2002, indem er ihnen große Mengen an Schlafmedikamenten verabreichte. Gestern wurde er nach langem Gerichtsverfahren des vierfachen Mordes schuldig gesprochen.

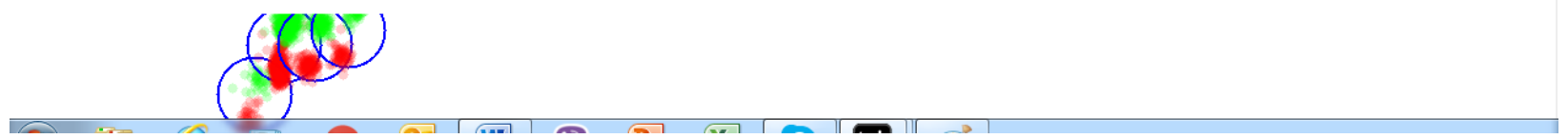

Figure 11. At the end of the (visually unmonitored) typing of 'Mordes', with the gaze on 'counts of murder following', the gaze (still in Win1) travelled right to 'Yesterday, he was found guilty' in preparation for the typing of 'schuldig gesprochen'. A typo in 'schuldig' brought the gaze down to Win2 (Shift 12). While the last four letters of the final word were being typed, the gaze had shifted up again to Win1 (Shift 13) to read the first clause of the next sentence, anchoring it to the last words of the previous sentence 'long trial.'.

\section{Discussion and some tentative conclusions}

Unlike a simultaneous interpreter's dependence on another person's rate of delivery, a translator producing a written translation can set the pace of reading and can freely reread if necessary. A translator can also freely control how much new ST to read before translating. This means that a translator's reading and writing style can directly reflect the individual translator's cognitive profile and preferences.

In the passage analysed above, from a technically fairly poor recording of one translator's gaze and keyboard activity while translating a single sentence, we claimed that gaze shifts were motivated by different needs and intentions. Shift 1 to Win1 aimed at harvesting a new translatable unit of new ST. 
This was also the aim of Shifts 3 and 5, both of which were followed by rereading of ST read earlier followed by reading of new text (anchoring new text in old text). With the reading following Shift 5, the whole ST sentence had been read. Therefore, the purpose of subsequent reading was not to read new text, but either to have a direct or very recent view of the segment under translation, especially where translation involved sequential restructuring of translatable units. Thus the rereading of 'following a long trial' after Shift 7 was triggered by the translator's decision to delete the translation of 'of four counts of murder' and to insert the translation of 'following a long trial' first. To ensure that this operation was done successfully, the translator took a fresh look at the relevant translatable unit before typing the translation of it. The same motivation appears to have underlain the rereading following Shift 9 of 'he was found guilty of four', which was instantly followed by the typing of the translation of 'of four'. Finally, the Win1 reading in Fig. 11 illustrates the translator's final wrap-up reading of the whole sentence to make sure everything has been covered before moving on to a new sentence.

Visual attention in Win2 was one of two kinds. The most common kind was visual attention to emerging text (visual monitoring of typing), e.g., on the typing of 'wurde' (Fig. 5), 'in Folge' (Fig. 8), 'nach langem Gerichtsverf(ahren)' (Fig. 9), 'des vier(fachen)' (Fig. 10), and '(sch)uldig gespro(chen)' (Fig. 11). There is reason to assume that such visual attention in no way precludes concurrent translational processing, e.g., in the form of continuing solution finding, as seen in the very quick execution of the change of 'Ver(fahren)' to 'Gerichtsverfahren' during a period of visual attention in Win2, where typing was being monitored (Fig. 9 and Figs. 1-3).

The second kind of visual attention in Win2 involved reading of existing TT. This occurred when the translator became aware that something was not right. The repeated reading of 'wurde er des vierfachen Morde' (Fig. 8) preceded the decision to delete 'des vierfachen Morde'. The new solution ('wurde er in Folge eines la') underwent similar, even more intensive and critical rereading for more than $4 \mathrm{~s}$. before that solution was also discarded. Finally, on a more superficial level, attention was also drawn to Win2 if a typo was noticed, and the correction of it needed to be closely attended to visually.

The main motivation that drives the translator's gaze to the ST window is the need to find something to translate next. With two windows on the screen, as in many translational setups, finding the next translatable unit seems to involve considerable redundancy in that a good deal more than seems strictly necessary is frequently read. There is reading before the new unit, and there may be reading beyond it. But as has already been suggested, much of the reading of 'old' text serves the purpose of anchoring new text in old text to ensure appropriate and connected reading of new ST and of appropriate attachment of new text to old in the TT.

A second important driver of visual attention to the ST is the translator's need to have a very recent look at the ST representation of the unit of which a translation is about to be typed, or even while it is being typed. A translator's remembrance of ST representations appears to either decay very quickly or to very quickly fall short of the desired directness of presence in the translator's memory. The constant cognitive presence of the ST is at once both necessary and not altogether desirable because of its negative priming potential. It is necessary because in the act of translation it must mentally and 
temporally coexist (in some form) with a target solution. It is undesirable because the strong presence of the written representation carries a risk of the ST priming translation options first suggested to the translator through formal similarity with the source text, which the translator has to suppress to avoid unwanted interference.

The main motivation for visual attention to emerging TT (in the bit analysed above) was to ensure that TT appeared correctly on the screen and that solutions were sufficiently accurate (as in the change from 'in Folge' to 'nach' for 'following') or sufficiently in agreement with TL sentence structure (as seen in the changes made in Fig.s 7-9). Shift 8 had a different motivation and showed how the translator's attention was shifted to reading and evaluating a solution that had been typed, but not yet fully accepted, and was therefore holding up production.

It is obvious that with gaze data we can know much more about where a translator's attention is when nothing is being typed. We can make much stronger guesses about what specific processing problem a translator was preoccupied with in a typing pause. But do we also get to know more about a translator's segmentation of text, of the scope of the units a translator works with?

The typing-pause-based analysis of segments above resulted in only three segments by a $1 \mathrm{~s}$. criterion and six by a $0.9 \mathrm{~s}$. criterion. Three segments were therefore borderline (with boundary pauses between 0.905 and $0.983 \mathrm{~s}$.) by the latter criterion. A further reduction of the boundary pause criterion to $700 \mathrm{~ms}$ would have yielded four further segments. In two of these latter cases, the pause was apparently caused by some editing activity. What this illustrates is that attention can very quickly be drawn to microphenomena relating to the typing of the target representation. But although such surface representation incidents are clearly reflected in the keystroke data, they are not helpful in identifying what larger segment or content was the translator's main focus at a given time. The keystroke-based segmentation based on the 0.9 s. criterion found the following seven segments: /Gestern wurde / er / des vierfachen Morde / $४ \varangle ४$ / in Folge eines la / $४ 4$ nach langem F Ver Gerichtsverfahren / des vierfachen Mordes schguldig gesprochen./. How well does this segmentation match with what the gaze data indicate?

Table 1. ST units read (row 1) and TT units read or monitored (row 2) during alternate visits to Win1 and Win2, with typing activity shown in the bottom row.

\begin{tabular}{|c|c|c|c|c|c|c|c|c|c|}
\hline $\begin{array}{l}\text { Win1: } \\
\text { Source text read } \\
\text { (or reread): }\end{array}$ & $\begin{array}{l}\text { Yesterday, } \\
\text { he was } \\
\text { found guilty } \\
\text { of four }\end{array}$ & $\begin{array}{l}\text { guilty of } \\
\text { four } \\
\text { counts of } \\
\text { murder }\end{array}$ & \multicolumn{3}{|c|}{$\begin{array}{l}\text { counts of murder following a } \\
\text { long trial }\end{array}$} & following a long trial & $\begin{array}{l}\text { Yesterday, he } \\
\text { was found } \\
\text { guilty }\end{array}$ & $\begin{array}{l}\text { found guilty of } \\
\text { four counts of } \\
\text { murder } \\
\text { he was found } \\
\text { guilty }\end{array}$ & $\begin{array}{l}\text { long trial. } \\
\text { He was } \\
\text { given four } \\
\text { life } \\
\text { sentences }\end{array}$ \\
\hline $\begin{array}{l}\text { Win2: Target text } \\
\text { read, reread or } \\
\text { monitored during } \\
\text { typing: }\end{array}$ & $\begin{array}{l}\text { Gestern॰wu } \\
\text { rde• }\end{array}$ & $\begin{array}{l}\text { wurde } \\
\text { er• }\end{array}$ & \multicolumn{3}{|c|}{$\begin{array}{l}\text { wurde er des vierfachen Morde } \\
\text { des vierfachen Morde } \\
\text { in Folge }\end{array}$} & $\begin{array}{l}\text { wurde er in Folge eines la } \\
\text { wurde er in Folge eines la } \\
\text { in Folge eines`nach langem F } \\
\text { Ver Gerichtsverf }\end{array}$ & $\begin{array}{l}\text { verfahren } \\
\text { des vier }\end{array}$ & $\begin{array}{l}\text { schguldig } \\
\text { gespro• }\end{array}$ & \\
\hline $\begin{array}{l}\text { Win2: } \\
\text { Target text typed } \\
\text { (segments by } 0.9 \\
\text { s. boundary } \\
\text { criterion): }\end{array}$ & \multicolumn{2}{|l|}{$\begin{array}{l}{[\cdot 01.529]} \\
\text { Gestern } \\
\cdot \text { wurde• } \\
{[\cdot 00.874] \mathrm{er}}\end{array}$} & $\begin{array}{l}{[\cdot 00.944]} \\
\text { des•vier } \\
\text { fachen• } \\
\text { Morde }\end{array}$ & $\begin{array}{l}{[\cdot 01.5} \\
60]< \\
44\end{array}$ & $\begin{array}{l}{[\cdot 00.905]} \\
\text { in } \cdot \text { Folge } \bullet \\
\text { eines } \bullet \\
{[\cdot 00.608]} \\
\text { la }\end{array}$ & 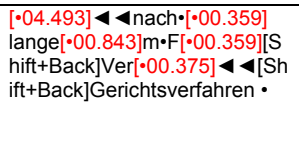 & \multicolumn{2}{|c|}{$\begin{array}{l}{[\cdot 00.983] \text { des } \bullet \text { vier }} \\
\text { fachen } \bullet \text { Mordes } \cdot[\cdot 00.765] \\
\text { schg } \cdot[\cdot 00.702] \triangleleft u[\cdot 00.234] \text { ldig } \bullet \\
\text { Gesprochen. }\end{array}$} & \\
\hline $\begin{array}{l}\text { Back translation } \\
\text { (typos excluded) }\end{array}$ & \multicolumn{2}{|c|}{ Yesterday, was he } & $\begin{array}{l}\text { of four } \\
\text { counts of } \\
\text { murde }\end{array}$ & 44 & $\begin{array}{l}\text { following } \\
\text { [1] a lo }\end{array}$ & following [2] a long trial & \multicolumn{2}{|c|}{$\begin{array}{l}\text { of four counts of murder guilty } \\
\text { found. }\end{array}$} & \\
\hline
\end{tabular}




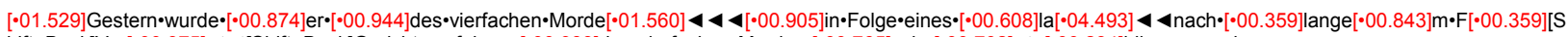
hift+Back]Ver[ $[\cdot 00.375] \triangleleft 4[$ Shift+Back]Gerichtsverfahren $\cdot[\cdot 00.983]$ des $\bullet$ vierfachen $\bullet$ Mordes $\bullet[\cdot 00.765]$ schg[ $[\bullet 00.702] \triangleleft u[\cdot 00.234]$ Idig $\bullet$ gesprochen

The great advantage of adding gaze data to keystroke data is that an explicit behavioural connection, rather than an inferred connection, is established between the ST and the emerging TT. By looking at activity per gaze shift, an explicit connection is established between what was just read in the ST and what was typed either more or less simultaneously or after some delay. The first 'chunk' of ST the translator read made it possible only to translate 'Yesterday, he was' ('Gestern wurde er') because the translator was aware, already before 'er' was typed, that more ST would have to be read in order to get the right constituent order in the German seeing that it would not be possible (by the translator's norms for correct German) to continue the sentence with: ${ }^{* \prime}$ Gestern wurde er schuldig gesprochen des vier [??]' or *'Gestern wurde er des vier [??] schuldig gesprochen'. Therefore Shift 3 to Win1 was necessary. While realising this, the translator typed 'er', clearly in response to what had been read after Shift 1. Therefore, from a reading point of view, 'er' should not be treated as a separate segment although the boundary typing pause before 'er' was very close to $0.9 \mathrm{~s}$.

The second ST reading sequence was unproductive in the sense that no target text was produced in response to what was read there. The gaze behaviour suggests an independent step, but with no match in the keystroke data. It added new text to the translator's memory, but the translator was at first either unable to make use of it or uncertain (Angelone 2010: 18) about how to use it.

Only after a second look at 'counts of murder' in the third ST reading sequence was the translator satisfied that it was possible to continue translating, and she therefore typed the translation of 'of four counts of murder' knowing that a correct and appropriate target construction like 'Gestern wurde er des vierfachen Mordes schuldig gesprochen' was now possible.

The representation of the reading process in the first row of Table 1 unfortunately does not have a proper temporal axis and therefore does not very clearly show how reading influenced the decision process, which is reflected more clearly in the keystroke data in the third row. But the clue to the decision to delete 'des vierfachen Morde' is in the gaze data. It was the unexpected discovery, as 'des vier' had just been typed, of a text unit ('following a long trial') that was not part of the translator's currently envisioned target sentence model and could not simply be added linearly to the existing target text, which suddenly forced the translator to produce a new target text model which would integrate the new unit. The unexpected new translatable unit was obviously at the centre of attention, but forced the translator to extend attention to the entire sentence construction and rethink it. This illustrates how a new unit of attention can suddenly force the translator to remodel a larger unit of attention so that it will be able to accommodate the smaller unit. The combination of gaze and keystroke data permits us to see that segments understood as cognitive units are not mere sections of a string, but are more like organic cells that can combine in multiple dimensions.

Once the decision had been made to restructure the order of the phrases so that the translation of 'following a long trial' came immediately after 'Gestern wurde er', 'des vierfachen Morde' was deleted, which cleared the relevant space for the continuation with 'in Folge'. This brought the structure of the 
German sentence into place: 'Gestern wurde er / in Folge eines langen Gerichtsverfahren / des vierfachen Mordes schuldig gesprochen', but typing stopped after 'la' in 'langen' because of a new problem concerning the interpretation of the relation signalled by 'following' between the ruling and the trial: Did 'following' suggest that the court's ruling was a result of or in accordance with ('in Folge') the trial, or did it simply suggest that the ruling was announced after ('nach') the trial, following it in time? After about four and a half seconds' reflection, the translator's first suggestion ('in Folge') finally gave way to the temporal interpretation with 'nach'.

Here, again, the gaze data was crucially informative about the scope of the unit of attention. The problem was obviously centred around the appropriateness of 'in Folge', which ended up being substituted by 'nach', but the gaze data show that the translator was reading and reviewing the larger unit 'wurde er in Folge eines la(ngen Gerichtsverfahren)', which was read repeatedly during more than four seconds. The unit of attention, again, was a unit within a unit: there was a locus of focused attention, but attention was as much on how it fitted into the larger area of attention.

The above account suggests a new way of identifying translation units on the basis of the translator's visual and cognitive search for translatable units and the occasional battle to integrate new units into the larger unit of the whole sentence or text. In the sentence we have analysed, there were three such units: (1) 'Yesterday, he was found guilty' (2) 'of four counts of murder' (3) 'following a long trial'. The restructuring challenge was to get from the original word order to: 'Yesterday, was he / following a long trial / of four counts of murder / guilty found', i.e., inverting 'he was' to 'was he', saving 'found guilty' till the end, moving the whole of (3) before (2) and then finally inverting 'found guilty' to 'guilty found'. To our very proficient translator, the structural challenge was so small that she could afford to prioritise translation by translatable unit and to only read ahead until such a unit had been captured. Structural changes and transitions between structural elements accounted for four of the five pauses (excluding the initial pause) with a duration $>0.9$ s., totalling 4.4 s., thereby taking up only about the same time as the one long pause before 'nach', which turned out to be the only seriously demanding challenge. After the decision to opt for 'nach', the rest was plain sailing with only three short visits to the source text.

Table 1 shows overall very fine correspondence between the units based on gaze shifts and units based on keystroke intervals $>0.9 \mathrm{~s}$. Not counting the final shift (Shift 13), which took the gaze into the sentence after the one we have analysed (after anchoring the reading in 'long trial'), there were six pairs of gaze shifts (ST $\rightarrow$ TT) and six keystroke-based segments. They did not exactly match, in part because of the translator's touch typing skills, which allowed the translator to read new ST before having finished typing the translation of a previously read portion of ST. The great advantage of identifying processing units on the basis of gaze shifts from ST reading to TT monitoring or reading, is that comprehension processes and production processes are brought together in a beautiful question-and-answer type of dialogue.

Acknowledgements: The author wishes to thank the editor and an anonymous reviewer for several very fine and helpful suggestions. 


\section{References}

Alves, F. and D. Vale. 2009. "Probing the unit of translation in time: Aspects of the design and development of a web application for storing, annotating, and querying translation process data”. Across Languages and Cultures 10(2). 251-273.

Angelone, E. 2010. "Uncertainty, uncertainty management and metacognitive problem solving in the translation task”. In: Shreve, G. and E. Angelone (eds.), Translation and Cognition [American Translators Association Scholarly Monograph Series XV]. 17-40.

Baddeley, A. D. 1986. Working Memory. Oxford: Clarendon Press.

Balling, L.W., K. T. Hvelplund and A. C. Sjørup 2014. “Evidence of parallel processing during translation”. Meta 59(2). 234-259.

Butterworth, B. 1980. “Evidence from pauses in speech”. In: Butterworth, B. (ed.), Language Production. Volume 1. Speech and Talk. London: Academic Press. 155-176.

Carl, M. and M. Kay. 2011. “Gazing and typing activities during translation: A comparative study of translation units of professional and student translators. Meta 56(4). 952-975.

Carl, M. and B. Dragsted 2012. "Inside the monitor model: Processes of default and challenged translation production”. Translation: Corpora, Computation, Cognition. Special Issue on the Crossroads between Contrastive Linguistics, Translation Studies and Machine Translation. 2(1). 127-145.

Chesterman, A. 1989. Readings in translation theory. Helsinki: Finn Lectura.

de Groot, A. M. B. 1997. “The cognitive study of translation and interpretation”. In: Danks, J. H., G. M. Shreve, S. B. Fountain and M. K. McBeath (eds.), Cognitive processes in translation and interpreting. London: Sage Publications. 25-56.

Dragsted, B. 2004. Segmentation in translation and translation memory systems. An empirical investigation of cognitive segmentation and effects of integrating a TM system into the translation process. [Ph.D dissertation]. Copenhagen: CBS.

Dragsted, B. 2005. “Segmentation in translation: Differences across levels of expertise and difficulty”. Target 17(1). 49-70.

Dragsted, B. 2010. "Coordination of reading and writing processes in translation : An eye on uncharted territory”. In: Shreve, G. M. and E. Angelone (eds.), Translation and Cognition [American Translators Association Scholarly Monograph Series; Nr. XV]. Amsterdam: John Benjamins Publishing Company. 41-62.

Dragsted, B., I. Gorm Hansen. 2008. “Comprehension and production in translation : A pilot study on segmentation and the coordination of reading and writing processes. Copenhagen Studies in Language 36. 9-29.

Goldman-Eisler, F. 1972. “Pauses, clauses, sentences”. Language and Speech 15(2). 103-113.

Immonen, S. and J. Mäkisalo. 2010. "Pauses reflecting the processing of syntactic units in monolingual text production and translation”. Hermes - Journal of Language and Communication Studies 44. 45-61.

Ivir, V. 1981. “Formal correspondence vs. translation equivalence revisited”. Poetics Today 2(4). 51-59.

Jakobsen, A. L. 2003. “Effects of think aloud on translation speed, revision, and segmentation”. In: Alves, F. (ed.), Triangulating Translation. Perspectives in Process Oriented Research. Amsterdam: Benjamins. 69-95.

Schilperoord, J. 1996. It's about Time. Temporal Aspects of Cognitive Processes in Text Production. Amsterdam: Rodopi. 
Timarová, S., B. Dragsted, and I. Gorm Hansen. 2011. “Time lag in translation and interpreting”. In: Alvstad, C., A. Hild and E. Tiselius (eds.), Methods and strategies of process research: integrative approaches in Translation Studie [Benjamins Translation Library 94]. Amsterdam: Benjamins. 121-146.

Tirkkonen-Condit, S. 2005. “The Monitor Model revisited: Evidence from process research. META 50(2). 405-414.

TPR-DB and Translog II: https://sites.google.com/site/centretranslationinnovation/. (accessed 09.03.2016) 